\title{
Liposarcoma of the spermatic cord: A case report
}

\author{
Murat Sambel, MD; ${ }^{*}$ Murat Demirbas, MD; Omer Yalcin, MD;+ Abdullah Erdogan, MD;* \\ Sedat Oner, MD;* Metin Kilic, MD;* Murat Aydos, MD*
}

*Sevket Yilmaz Education and Research Hospital, Department of Urology, Bursa, Turkey; ' Sevket Yilmaz Education and Research Hospital, Department of Urology and Pathology, Bursa, Turkey

Cite as: Can Urol Assoc J 2015;9(7-8):E527-30. http://dx.doi.org/10.5489/cuai.2827

Published online July 17, 2015.

\section{Abstract}

Spermatic cord liposarcoma is very rare and characterized by a painless inguinal or scrotal mass. This is a case report of a 66-yearold man presenting with a mass in his left scrotum. Inguinal orchiectomy was performed and the histopathological examination revealed a liposarcoma of the spermatic cord.

\section{Introduction}

Liposarcoma of the spermatic cord (LSC) is very rare, representing about $7 \%$ of paratesticular sarcomas. ${ }^{1}$ Rodriguez and colleagues described the largest cohort study of spermatic cord tumours, including 362 patients and the most common types were liposarcoma $(46 \%){ }^{2}$ To the best of our knowledge, only about 200 cases of LSC have previously been reported in the English written literature. Most were reported in adults, presenting as a painless inguinal or scrotal mass, and were usually mistaken for an inguinal hernia or hydrocele. Preoperative diagnosis has been seldom reported. Until now, the published literature on LSC has been limited to case reports with limited clinical information. ${ }^{3}$ We present a case of LSC, which was only be diagnosed after histopathological examination.

\section{Case presentation}

A 66-year-old male was admitted to our clinic complaining of scrotal pain for 20 days. He also reported left upper scrotal mass for 6 months, which was rapidly growing in last 2 months.

Our patient had a non-significant medical history, including lack of local trauma, infection, weight loss, and voiding complaints. Physical examination showed a large, non-tender, mobile left scrotal mass, which did not exhibit trans-illumination. All preoperative laboratory examinations, includ- ing complete blood count, biochemistry and chest X-ray, were normal; beta-human chorionic gonadotropin ( $\beta-\mathrm{HCG})$, lactate dehydrogenase (LDH), and Alpha-fetoprotein (AFP) levels were also normal.

Scrotal ultrasound examination revealed a heterogeneous mass involving the left spermatic cord, which indicated a high suspicion of malignancy with normal testis echo. Magnetic resonance imaging (MRI) examination has showed a mass extending from over the left testis upper pole to the inguinal ring, measuring $11.5 \times 5.3 \times 6.3 \mathrm{~cm}$. The lesion had low signal intensity on T1-weighted images and high signal intensity on T2-weighted images (Fig. 1).

Based on these findings, we performed exploratory surgery via a left inguinal approach, in which a well-demarcated 8 $\times 6 \times 7 \mathrm{~cm}$ round mass, involving the spermatic cord and located above the left testis and epididymis, was explored. The mass was inseparable from the cord. There was no evidence of inguinal hernia. A radical left orchiectomy was performed with wide excision and high ligation of the spermatic cord. The mass was measured $6 \times 5.5 \times 4.5 \mathrm{~cm}$ and it was described as well-encapsulated, spherical, soft, and pink-yellow in colour and attached to the spermatic cord (Fig. 2).

The sampling tissues were fixed in $10 \%$ formalin and then processed in a fully-enclosed automatic tissue processor system for 16 hours. The $4-\mu \mathrm{m}$ thick sections, which were obtained from paraffin embedded tissues, were stained with hematoxylin-eosin and examined under a light microscope. Histologically, the tumour was composed of contiguous sheets of fibroblastic spindle cells with nuclear atypia, often organized in a fascicular pattern, and sheets of backto-back round lipoblastomatous cells with vacuolated cytoplasm (Fig. 3). Abrupt transition between tumoral patterns, as well as intermingling pattern (Fig. 4) of morphologically distinct tumoral cells, is conspicuous. Tumoral cells have sparse nucleoli and mitotic figure. The final histopathological diagnosis as confirmed as de-differentiated liposarcoma.

Histological examination revealed a dedifferentiated liposarcoma of the cord with tumour-free margins of resection and no lymphovascular invasion. The patient had a good 


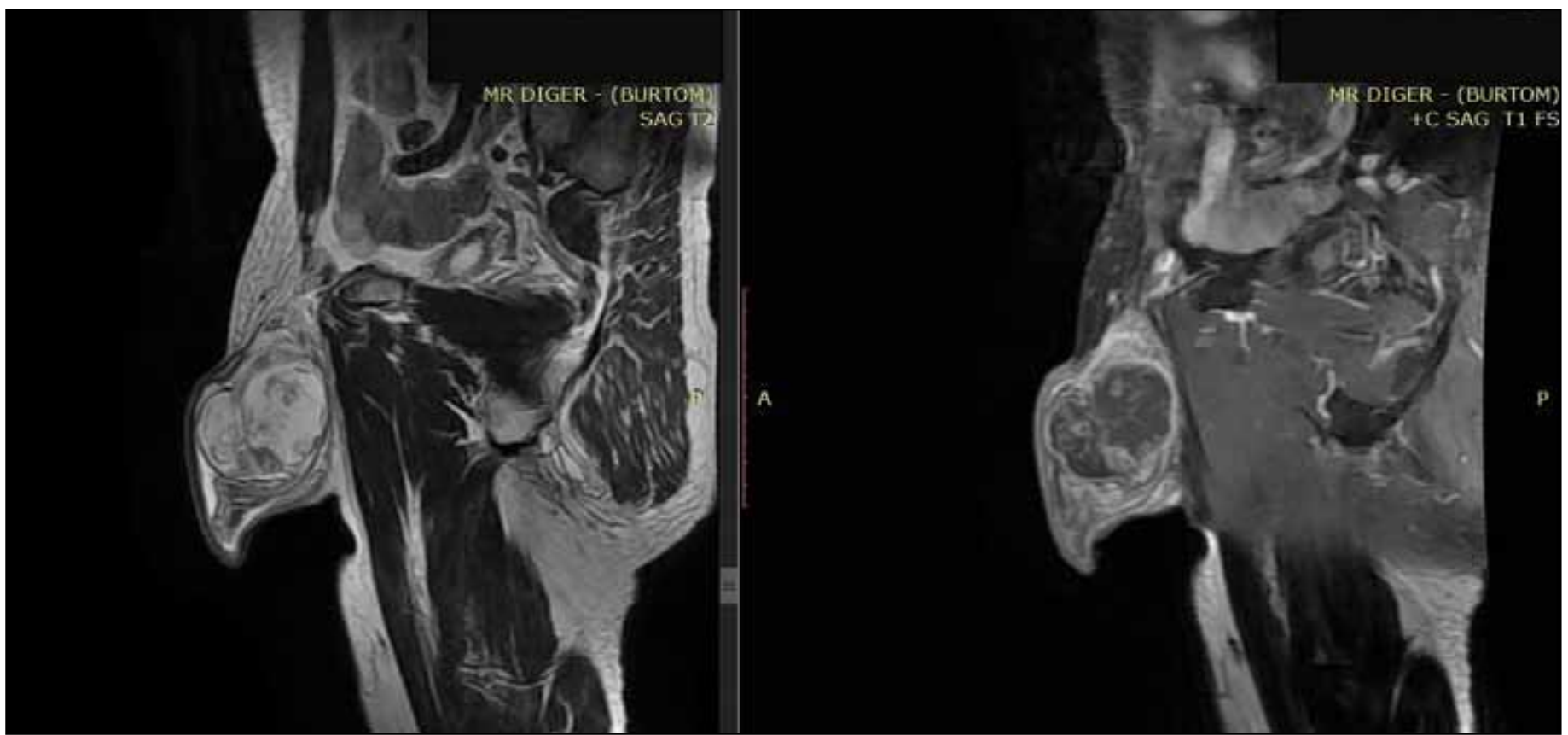

Fig. 1. Sagittal magnetic resonance images showing a mass, extending from over the left testis upper pole to the inguinal ring. The lesion had low signal intensity on T1-weighted images (right figure) and high signal intensity onT2-weighted images (left figure).

postoperative clinical course, with no complications and was discharged on postoperative day 2 . Close follow-up is being held in conjunction with the medical oncologist.

\section{Discussion}

Liposarcoma of the paratesticular tissues (spermatic cord, testicular tunica or epididymis), was first reported in $1952 .{ }^{4}$ It is a rare type of neoplasm, comprising about $5 \%$ to $7 \%$ of all paratesticular sarcomas. ${ }^{5,6}$ Most of them originate in the spermatic $\operatorname{cord}^{7}$ but some in the retroperitoneum, and they

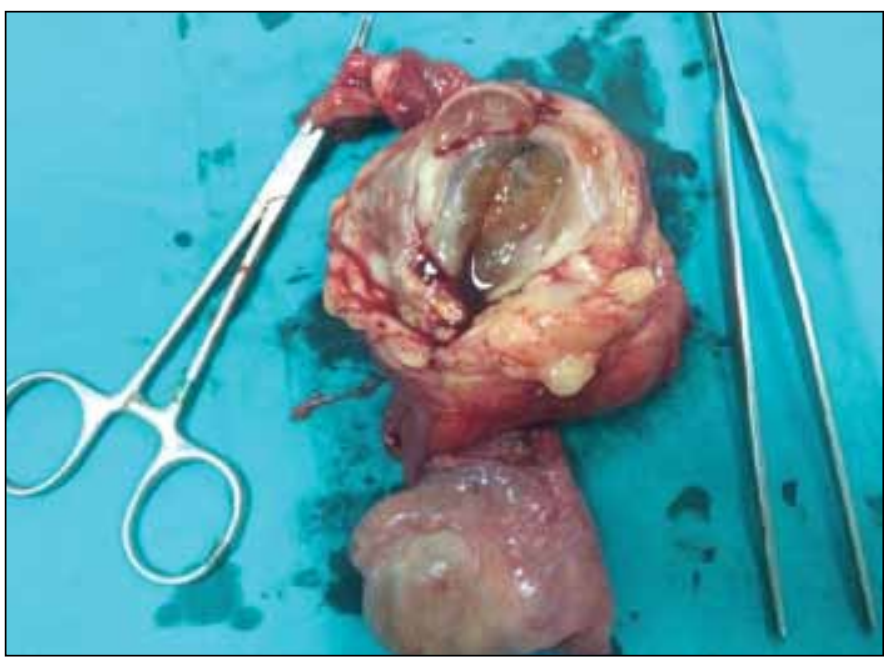

Fig. 2. Gross appearance of the mass. develop in the inguinal region, involving the spermatic cord. ${ }^{8}$ In our case, the lesion originated in the spermatic cord. The tumour occurs mostly in adults and the mean age at presentation is 61 years. The duration of symptoms ranged from 1 week to 5 years. ${ }^{3}$ Our patient's age was consistent with the literature. A relatively higher incidence has been reported in Japanese men (nearly one-fourth of the reported cases), but the cancer has been reported worldwide. ${ }^{9}$ The typical clinical manifestation of LSC is a slowly growing, non-tender, painless, nodular mass of varying size, located intra-scrotally above the testis or in the groin. ${ }^{10}$ In our case, total duration of

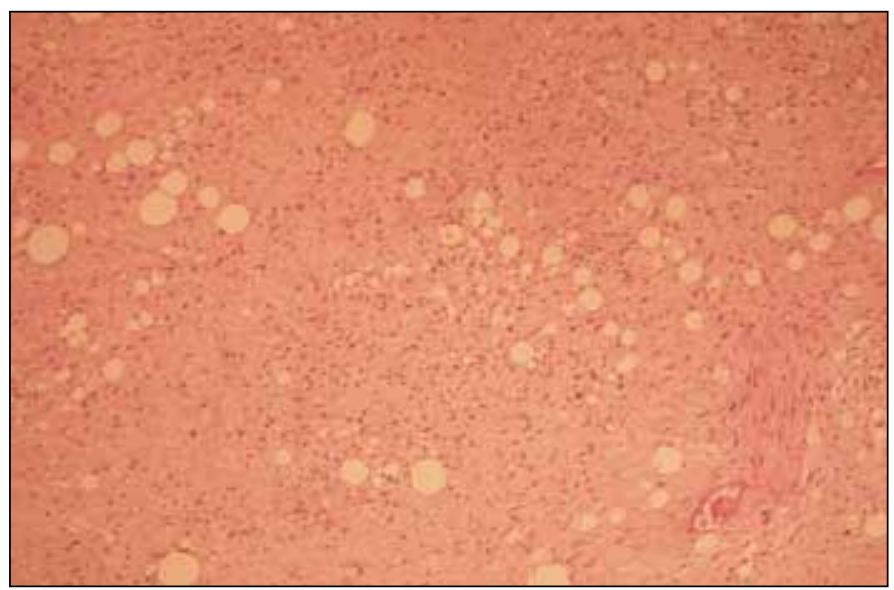

Fig. 3. De-differentiated liposarcoma. Abrupt transition between well differentiated liposarcoma, high-grade non-lipogenic area with spindle cells and a pattern reminiscent of neural structure (look at right lower) is seen. Hematoxylin \& eosin stain, $\times 40$. 


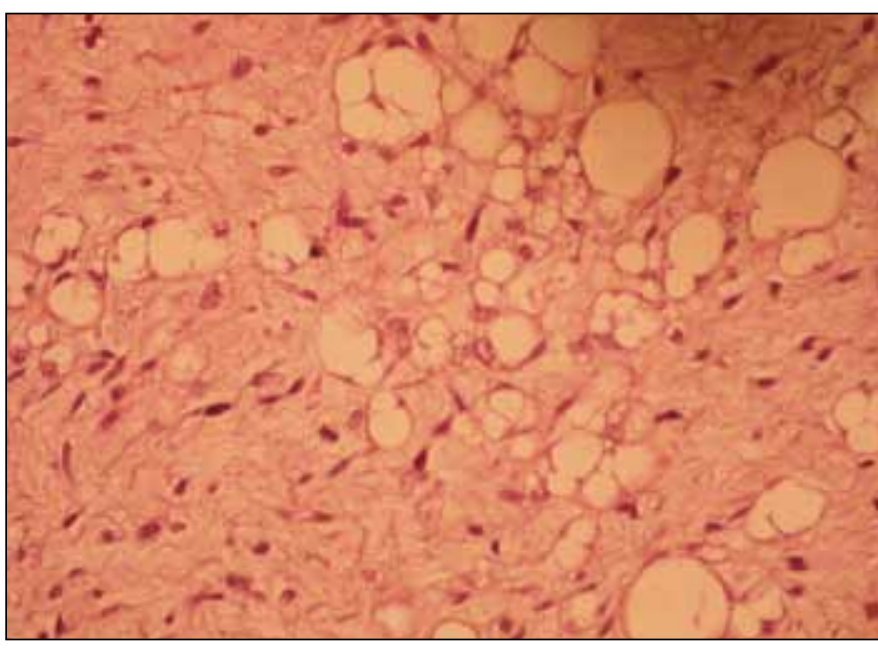

Fig. 4. Intermingled area, low grade liposarcomatous cells and pleomorphic short-spindled cells. Hematoxylin \& eosin stain, $\times 400$.

symptoms was 6 months with more rapid progression in last 2 months. Our patient revealed scrotal pain in last 20 days before admission. LSC are usually painless.

High-resolution ultrasonography, contrast enhanced computed tomography and MRI are reliable imaging modalities for the scrotum and its contents, and all can provide useful information about the lipomatous nature of these masses. ${ }^{11-13}$

We initially performed scrotal ultrasonography in our case and it revealed the heterogeneous mass of the LSC, but it obtained indecisive information about the lesion and we had to perform an MRI to confirm either malignant or benign distinction. A scrotal MRI was performed because of its ability to produce very accurate resolution images of the soft tissues and to provide valuable information about local extension of the lesion. From the MRI, however, we could not ascertain whether the lesion was malignant or benign, and we were also not able to exclude the possibility of the presence of an inguinal hernia. At the end, we preferred to perform a radical orchiectomy for definitive diagnosis and pathological examination revealed the liposarcoma of the cord.

LSCs usually present as operative or histological surprises. The recommended treatment is surgery in the form of wide local excision, which in most cases is a radical orchiectomy from as close to the deep ring as possible. There is no indication for routine lymph node dissections as the locoregional lymph nodes are rarely involved. The outcome is fairly good in most cases if the resection is microscopically free from malignant cells. Adjuvant radiotherapy is usually not required except in cases with positive margins or local recurrence and poor prognostic factors. There is no definite role of chemotherapy, which is recommended mostly in recurrent cases. These cancers have a known risk of local recurrence, hence a long-term follow-up up to 10 years is mandatory. Recurrences even after 20 years from the diagnosis have been reported. ${ }^{9,14,15}$
The prognosis of paratesticular liposarcomas depends on the histological cell type, among well-differentiated, dedifferentiated, pleomorphic and myxoid/round cell types. The well-differentiated and myxoid/round cell types have a better prognosis, but they tend to have a high incidence of local recurrence. ${ }^{16}$ In our case, pathological examination of the specimen revealed a dedifferentiated subtype of liposarcoma. In the postoperative evaluation, an abdominal CT was performed and there was no sign of any metastasis or pathologic lymph nodes. The patient was directed to medical oncology for follow-up and further treatment.

\section{Conclusion}

In the presence of a rapidly growing, non-tender, painless, nodular mass of varying size, located intra-scrotally above the testis or in the groin, a paratesticular tumour, more specifically a spermatic cord tumour (such as liposarcoma), should be part of the differential diagnosis.

Competing interests: The authors all declare no competing financial or personal interests.

This paper has been peer-reviewed.

\section{References}

1. Sogani P, Grabstald H, Whitmore Jr. W.F. Spermatic cord sarcoma in adults. J Urol 1978;120:301-5.

2. Rodriguez D, Barrisford GW, Sanchez A, et al. Primary spermatic cord tumors: Disease characteristics, prognostic factors, and treatment outcomes. Urol Oncol 2014;32:19-25. http://dx.doi.org/10.1016/i. urolonc.2013.08.009

3. Li F, Tian R, Yin C, et al. Liposarcoma of the spermatic cord mimicking a left inguinal hernia: A case report and literature review. World J Surg Oncol 2013;25:11-8. http://dx.doi.org/10.1186/14777819-11-18

4. Schwartz SL, Swierzewski SJ 3rd, Sondak VK, et al. Liposarcoma of the spermatic cord: report of 6 cases and review of the literature. J Urol 1995;153:154-7. http://dx.doi.org/10.1097/00005392199501000-00055

5. Bhosale PR, Patnana $M$, Viswanathan C, et al. The inguinal canal: Anatomy and imaging features of common and uncommon masses. Radiographics 2008;28:819-35. http://dx.doi.org/10.1148/ rg. 283075110

6. GarcíaMorúa A, Lozano Salinas JF, Valdés Sepúlveda F, et al. Liposarcoma of the spermatic cord: Our experience and review of the literature. Actas Urol Esp 2009;33:811-5. http://dx.doi.org/10.1016/ S0210-4806(09) 74235-4

7. Treadwell T, Treadwell MA, Owen M, et al. Giant liposarcoma of the spermatic cord. South Med J 1981;74:753-55. http://dx.doi.org/10.1097/00007611-198106000-00029

8. Noguchi H, Naomoto $Y$, Haisa $M$, et al. Retroperitoneal liposarcoma presenting an indirect inguinal hernia. Acta Med Okayama 2001;55:51-4.

9. Coleman J, Brennan MF, Alektiar K, et al. Adult spermatic cord sarcomas: Management and results. Ann Surg Oncol 2003;10:669-75. http://dx.doi.org/10.1245/aso.2003.11.014

10. Vorstman B, Block NL, Politano VA. The management of spermatic cord liposarcomas. J Urol 1984;131:66-9.

11. Yoshino T, Yoneda K, Shirane T. First report of liposarcoma of the spermatic cord after radical prostatectomy for prostate cancer. Anticancer Res 2009;29:677-80.

12. Hsu YF, Chou YY, Cheng YH. Spermatic cord myxoid liposarcoma presenting as an incarcerated inguinal hernia: Report of a case and review of literatures. Hernia 2012;16:719-22. http://dx.doi.org/10.1007/ s10029-011-0803-3

13. Cheng YC, Chou YH, Chiou HJ. Liposarcoma of the spermatic cord: A report of two cases and a review of the literature. J Med Ultrasound 2004;12:125-30. htrp://dx.doi.org/10.1016/S0929-6441 (09)60098-9 
Sambel et al

14. Hinman F, Gibson TE. Tumors of the epididymis, spermatic cord and testicular tunics: A review of literature and report of three new cases. Arch Surg 1924;8:100. http://dx.doi.org/10.1001/archsurg. 1924.01120040111005

15. Demirci U, Buyukberber $S$, Cakir $A$, et al. Synchronous testicular liposarcoma and prostate adenocarcinoma: A case report. Cases I 2010;3:27. http://dx.doi.org/10.1186/1757-1626-3-27

16. Stranne J, Hugosson J, Lodding P. Post-radical retropubic prostatectomy inguinal hernia: An analysis of risk factors with special reference to preoperative inguinal hernia morbidity and pelvic lymph node dissection. J Urol 2006;176:2072-6. http://dx.doi.org/10.1016/i.juro.2006.07.007
Correspondence: Dr. Murat Demirbas, Sevket Yilmaz Education and Research Hospital, Department of Urology, Turkey, muratdemirbas@doctor.com 